\title{
PSIQUÊ, DE ANGELA LAGO: DIÁLOGOS INTERTEXTUAIS DO VERBAL E DO NÃO VERBAL
}

Sandra Trabucco Valenzuela (UAM)

Resumo: O artigo analisa e interpreta o livro-ilustrado Psiquê, de Angela Lago, revisando o diálogo intertextual com o verbal e o não verbal, com pinturas, fotografia, cinema, história e a referência mitológica que é a base narrativa do conto; discute sobre os diferentes conceitos de literatura infantil e como Psiquê pode ser lido na contemporaneidade. Palavras-chaves: Angela Lago, Eros e Psiquê, Literatura infantil, Arte e Literatura, Mitologia Grega, Literatura e Cinema.

Resumen: El artículo analisa e interpreta el libro-ilustrado Psiquê, de Angela Lago, revisando el diálogo intertextual con lo verbal y no verbal, con obras de arte, fotografía, cine, historia y la referencia mitológica que es base narrativa del cuento; discute sobre los diferentes conceptos de literatura infantil y cómo se lee Psiquê en la contemporaneidad.

Palabras-clave: Angela Lago, Eros y Psiqué, Literatura infantil, Arte y Literatura, Mitología Griega, Literatura y Cine.

Contar histórias é uma prática social que acompanha o ser humano desde a existência das primeiras sociedades. A linguagem e o símbolo corporificam a percepção da realidade em seus diversos níveis: "Em todas as cosmogonias míticas, por mais longe que remontemos em sua história, sempre volvemos a deparar com esta posição suprema da Palavra" (CASIRER, 2000, p.64).

As narrativas, por sua vez, sustentam-se pela atividade simbolizante desenvolvida pelo ato de contar, interpretando o mundo e expressando a percepção e as relações entre o 
"eu" e o "outro". História, mitos, lendas, anedotas, costumes e tradições compõem narrativas orais que mais tarde são fixadas através da escrita. A literatura popular, narrativas míticas e contos maravilhosos atestam o predomínio do pensamento mágico na apreensão da realidade através do sensível e do intuitivo (COELHO, 1984, p.21).

As mitologias primitivas foram a fonte de narrativas primordiais, transmitidas oralmente, recontadas e miscigenadas com tradições e mitos ulteriores de outros povos, que configuraram arcabouço religioso, mítico, folclórico e literário de múltiplas culturas.

Pode-se definir o mito como o relato de um acontecimento que teve lugar em um tempo primordial, o tempo fabuloso do princípio, uma narrativa da criação, ou seja, de como um mundo começou a existir, das façanhas de deuses e entes sobrenaturais e suas ações relativas ao Sagrado. Nas palavras de Mircea Eliade,

O mito conta uma história sagrada [...]. O mito fala apenas do que realmente ocorreu, do que manifestou plenamente. [...] é em razão das intervenções dos Entes Sobrenaturais que o homem é o que é hoje, um ser mortal, sexuado e cultural. (ELIADE, 2004, p.11)

As narrativas primordiais, portanto, aportam valores e padrões de uma cultura, circunscrevem-se na literatura 
popular e, mais tarde, manifestam-se na literatura destinada a adultos e crianças, transmitindo de forma poética e metafórica padrões de pensamento e conduta, sejam estes de natureza religiosa, política, social, ética, artística, entre outras.

A literatura escrita especificamente para o público infantil surge no século XVII, unindo preceitos artísticos e, muitas vezes, intenções pedagógicas, como as fábulas de Jean La Fontaine (1621-1695). Por sua vez, Charles Perrault (1628-1703) introduziu na literatura francesa as lendas e narrativas da tradição oral, buscando o caráter pedagógico que consagraria o nascimento da literatura dita infantil, com a publicação em 1697 de sua primeira coletânea, História do tempo passado com moralidades, também conhecida como Contos da Mamãe Gansa (Les Contes de ma Mère l'Oye). Vale dizer que, na edição original, a Mamãe Gansa era representada pela figura de uma fiandeira, seguindo a tradição que associa as Parcas com as fadas, reforçando seu caráter de traçar o destino. As Parcas são personagens mitológicas que tecem os fios da vida de cada ser humano, sendo: Cloto, a responsável pelo nascimento; Láqueses, cuja atribuição era girar o fuso e assim tecer a vida, e Átropos, encarregada de cortar o fio da vida. Nesta primeira compilação, Perrault recolheu e adaptou ao gosto da tradição literária francesa contos 
populares como A Bela adormecida, Chapeuzinho vermelho, As fadas, A Gata borralheira, O Barba azul, O gato de botas e $O$ pequeno polegar.

Contemporâneos a Perrault, estão Fénelon (1651-1715) que escreveu exemplaridades; Madame D’Aulnoy (MarieCatherine Le Jumel de Barneville, Baronesa D'Aulnoy, 1650/51-1705) autora de O pássaro Azul e A bela dos cabelos de ouro. Já no século XVIII destacam-se Jonathan Swift (16671745) com As viagens de Gulliver; Madame Jeanne-Marie Le Prince de Beaumont (1711-1780), com A Bela e a Fera, O Príncipe encantado e $A$ fada das ameixas. Durante o período romântico, no século XIX, muitos artistas desenvolvem a literatura dos contos maravilhosos e dos contos de fada. $\mathrm{O}$ dinamarquês Hans Christian Andersen (1805-1875) escreveu 156 contos, dentre os quais estão: A pequena sereia, $O$ rouxinol, A roupa nova do imperador, Sapatinhos vermelhos e $O$ patinho feio.

Pioneiros no estudo do folclore, os Irmãos Grimm - Jacob (1785-1863) e Wilheim (1786-1859) - colheram contos e lendas populares conhecidos na Alemanha, publicando alguns dos contos mais conhecidos da literatura, entre eles: Branca de Neve, Cinderela, Rapunzel, Chapeuzinho vermelho, A Bela adormecida, Hansel e Gretel (João e Maria) e Rumpelstiltskin. 
O século $X X$ coloca em questão a finalidade da literatura infantil: as obras deveriam instruir ou divertir, trata-se de Arte ou de instrumento pedagógico? Os movimentos de vanguarda contribuem para a reflexão sobre o objeto da literatura e em especial da literatura infantil e juvenil: "longe de pretender a exemplaridade ou a transmissão de valores já definidos ou sistematizados, [a literatura infantil] busca estimular a criatividade, a descoberta ou conquista dos novos valores em gestação" (COELHO, 1984, p.27). O lúdico, a disposição gráfica, o jogo com o verbal e o não verbal evidenciam uma busca por novas formas de leitura.

A literatura infantil contemporânea é fruto de empréstimos dos mais diversos gêneros literários, além de suportes e obras provenientes de outros meios, como cinema, videoclipe, filmes de animação, artes plásticas, produções de áudio, histórias em quadrinhos e linguagem digital aplicada em videogames.

De acordo com Pullman, os livros-ilustrados diferenciamse daqueles com ilustrações em sua "complexidade na interação entre significado da imagem e significado do texto" (PULLMAN, 2010). Os livros-ilustrados permitem ler palavras e imagens sem a limitação da sequência linear, ampliando as possibilidades semióticas e semântico, numa interação 
inusitada entre imagem e texto. Este é o caso do livroilustrado Psiquê, escrito e ilustrado por Angela Lago (2010).

Angela Maria Cardoso Lago nasceu em Belo Horizonte, em 1945, onde passou a infância; formou-se na Escola de Serviço Social da Pontifícia Universidade Católica de Minas Gerais em 1968. Em 1969, segue para Denver, no Colorado (EUA), para fazer um curso de psicopedagogia infantil; entre 1970 e 1973, para acompanhar o trabalho de seu marido, reside na Venezuela, onde leciona na Escola de Serviço Social. Entre 1973 e 1975, segue para o Reino Unido e cursa artes gráficas no Napier College de Edimburgo. De volta ao Brasil, dedicase à literatura infantil. Em 1980, lança seus primeiros livros escritos e ilustrados por ela própria: $O$ fio do riso e Sangue de barata. Na década seguinte, valendo-se de diversas técnicas de produção de ilustrações, lança dez livros, entre eles Festa no céu (1995). Atualmente, dedica-se exclusivamente à produção literária infantil, como ilustradora e escritora, somando mais de 30 títulos publicados.

Em depoimento publicado em seu site pessoal, Angela Lago destaca sua preferência por elementos da cultura popular, da tradição oral e do folclore, como matérias primas para suas narrativas e ilustrações, contando a história através de imagens trabalhadas seja à mão ou no computador, brincando 
com a linguagem cinematográfica, imagens da literatura de cordel, texturas, dobraduras e com a própria materialidade do livro, ou seja, suas costuras, cortes e paginação.

Em sua obra, Angela Lago propõe ao leitor a sua versão do mito de Eros e Psiquê. Embora disponha de inúmeras versões decorrentes da transmissão oral e das diversas teogonias, o mito tem como tema o amor cego capaz de enfrentar todos os obstáculos para ser vivenciado.

Nas tradições mais antigas, Eros, o Amor, consiste numa divindade contemporânea de Gaia, "oriundo do Caos inicial e cultuado sob a forma de uma simples pedra (ou então nascido do Ovo primordial engendrado por Nix (a Noite))" (KURY, 1994, p.130). Nas duas versões referidas por Kury, Eros é uma força preponderante na ordem do universo, responsável pela reprodução e perenidade de todas as espécies, de modo a garantir a harmonia do Cosmos.

Em $O$ banquete, de Platão, Diotima, uma filósofa grega, conta a Sócrates outra versão do mito do nascimento de Eros: durante o banquete em comemoração ao nascimento de Afrodite, Penia (a Pobreza) aproximou-se de Poros (o Esperto), filho de Métis (a Prudência), para pedir sobras da festa. Embriagado de néctar, Poros adormeceu e Penia deitou-se com ele, concebendo Eros. Por isso, Eros - cujo 
fado era ser pobre, rude, sujo, sempre descalço -, sem lar, dorme no chão ou nas ruas, sem conforto, sem beleza ou delicadeza. Por herança paterna, Eros dirige a atenção a tudo o que é belo e gracioso, é valente e audacioso, obstinado e grande feiticeiro. Ele é um paradoxo, vive entre a miséria e a opulência, entre a tolice e a sabedoria; passou a acompanhar e servir Afrodite (Platão, s/d, p.109-112).

Outras versões do mito, que se tornaram mais populares dão conta de que Eros (ou Cupido) é filho de Afrodite (Vênus) e Ares (Marte) ou ainda, de Afrodite e Hermes (Mercúrio). Na versão latina, Cupido, o Amor, acompanha sempre a mãe; porém, cansada de vê-lo permanecer como uma criança, Vênus recorre aos conselhos de Têmis, que the sugere ter outro filho. Nasce, então, Anteros - justamente o oposto de Cupido, ou seja, desamor, antipatia, aversão, representação do amor não correspondido - e Cupido começa a crescer. Outra narrativa conta que, ao reconhecer em Eros um ente capaz de criar inúmeras perturbações, Zeus quis que Afrodite se desfizesse do bebê. A deusa, entretanto, optou por esconder o filho nos bosques, onde foi alimentado por animais ferozes e aprendeu a manipular as flechas ardentes do arco que provocaria o amor nos seres humanos. Sua representação se dá muitas vezes com asas de abutre, 
revelando sua face perigosa, pois, ao lançar suas setas, impõe o Amor a homens e mulheres (PUGLIESI, 2003, p.32-34).

Através de recursos gráficos, Angela Lago oferece ao leitor infantil (e, é claro, também ao adulto) uma narrativa complexa capaz de reunir as diversas versões do nascimento de Eros e sua união com Psiquê, com a versão mais conhecida contada pelo autor latino Lúcio Apuleio (125-170 d.C.) em sua coletânea Metamorfoses ou $O$ asno de ouro, onde são narradas, em onze livros, as façanhas de um certo Lúcio, transformado por arte de mágica em burro, mas que, ao final, recupera suas feições humanas (LEONI, 1967, p.118).

No primeiro contato com o livro, através da capa preta, salpicada de pontos prateados brilhantes, representa-se a noite (Nix), uma das versões do nascimento de Eros. Esse recurso imagético dispensa a inserção literal do nome "Eros" na capa, ao lado de Psiquê. Eros nasce da Noite; no entanto, o nome "Psiquê" destaca-se das trevas, encabeçado pelo nome da autora. Embora o mito seja comumente referido como "Eros e Psiquê", a capa destaca o aspecto feminino ao abordar a história desta em busca do Amor. 


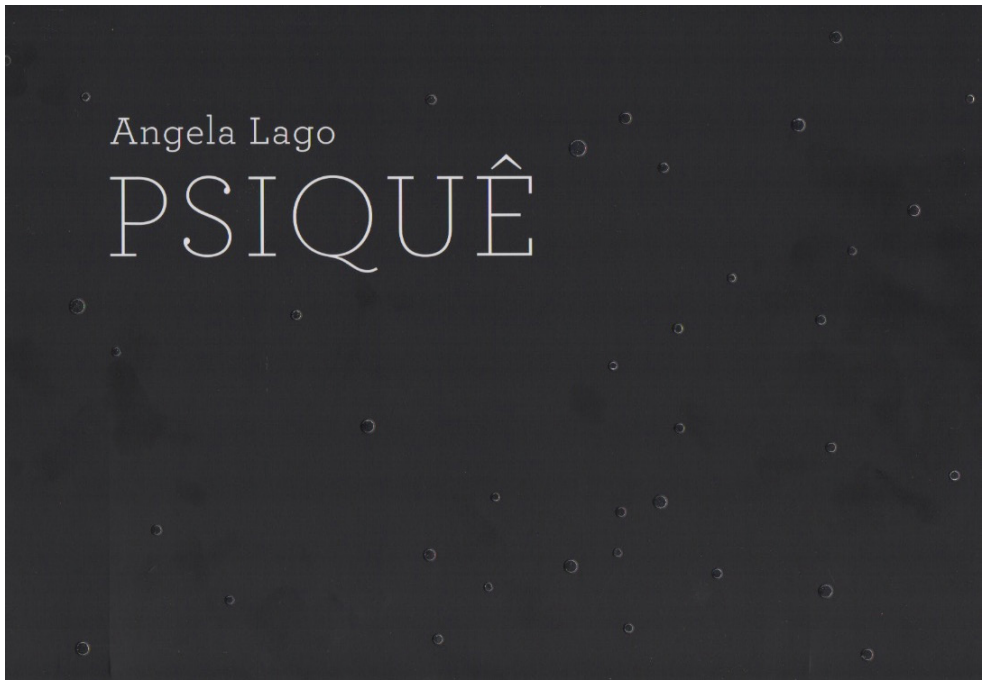

Figura 1

Capa: Psiquê, de Angela Lago.

Ao abrir o livro, uma orelha escura sustenta uma página prateada e brilhante, que se opõe, ao lado de outra, que reproduz a imagem da noite com o céu estrelado, mas desta vez, apenas com pontinhos brancos.

Na página seguinte (considerando que as páginas não são numeradas), temos em uma nova página pontinhos brancos ainda menores. Ao lado, consta o nome da Editora Cosac Naify e o título da obra Psiquê, em laterais opostas. A noção de distanciamento da personagem configura-se, portanto, graficamente desde o início da obra.

A seguir, abre-se outra página com o nome da autora e o título do livro na lateral direita. Ao centro, unindo as duas 
páginas, temos um arbusto com muitos galhos à mostra, dividido simetricamente ao meio, mas cercado de sombras.

O primeiro texto surge antecedido por uma pequenina borboleta: "Esta história é de encantamento. Traz vida longa e boa sorte a todos que a escutam ou a leem" (LAGO, 2010). Estas orações marcam a presença da instância narrativa, constituindo o exórdio, ou seja, do ponto de vista da retórica clássica, o narrador indica o assunto a ser tratado no discurso, propondo um elogio para aquele que se aventura a compartilhar o texto.

A narrativa assume o ponto de vista de Psiquê (em grego, $\Psi$ uxń), cujo termo apresenta dois significados: "borboleta", "alma", "respiração" e o "si mesmo", isto é, o que a Psicologia convencionou chamar de "ego". Com base nesses significados, surgem, no livro, pequenas borboletas, muitas vezes camufladas entre folhas ou mesmo de tamanho muito reduzido, exigindo do leitor um aguçamento da visão; a imagem dos personagens acaba sendo difusa, pois representam "almas" e não seres de carne e osso.

$\mathrm{Na}$ próxima folha, desencadeia-se a narrativa propriamente, acompanhada da ilustração de uma paisagem noturna, num monte verde musgo sobre o qual se projetam sete sombras que parecem caminhar cabisbaixas. Como uma 
tradicional narrativa de encantamento, o início do discurso é marcado pela expressão "Era uma vez".

Seguindo Apuleio, a instância narrativa conta a história da personagem, uma princesa que, de tão bela, despertara ciúmes em Afrodite. A beleza dela é tanta que não pode ser descrita e muito menos desenhada: este recurso de não desenhar a imagem de Psiquê permite ao leitor imaginar sua beleza, sem amarras na realidade ou estereótipos dados pela narração.

A vingativa Afrodite envia seu filho Eros, o deus do amor, para que Psiquê se apaixone pelo "mais terrível dos seres" (LAGO, 2010). Contudo, ao ver a princesa, acaba enamorado. Como era o costume, o rei recorreu ao oráculo para saber o destino da filha, descobrindo então que ela "se casaria com um monstro, uma fera que voa, queima e fere" (LAGO, 2010). Metaforicamente, essa é a descrição de Eros: representado com asas, Eros voa, queima usando o fogo de suas flechas e fere os seres ao despertar-lhes o sentimento do Amor.

Psiquê manteve-se forte, aguardando seu destino, como mostram as páginas seguintes, ao exibir uma sombra solitária projetada sobre a mesma montanha noturna da imagem anterior. Prevalece na imagem a escuridão da noite, sublinhada com um único texto, comprido no canto 
inferior esquerdo, que dá sequência à oração iniciada na página anterior: "sozinha". A frase se completa na página posterior: "na beira do abismo" (LAGO, 2010). O monte está posicionado no canto superior esquerdo, com a sombra dela também invertida, como se esta fosse se lançar de cabeça ao abismo soturno e solitário.

As imagens seguintes mostram um novo cenário, porém não menos lúgubre, e o texto esclarece: "Mas um vento carregou Psiquê para um castelo" (LAGO, 2010). O castelo é rodeado de árvores, com troncos grossos, mas folhagem pouco espessa. Sombras dos galhos sobrepõemse às imagens dos troncos na entrada do castelo. $O$ portal é composto de um mosaico de pequenas borboletas. Duas borboletas se destacam na paisagem, uma colorida ao centro, representando Psiquê, e outra sobre a entrada do castelo. Na história de Apuleio, é o Vento Oeste ou Zéfiro quem a transporta.

Nas duas páginas a seguir, Psiquê entra no castelo, observa-se a sombra projetada sobre a janela, com o texto: "Seres invisíveis Ihe serviram e tocaram música" (LAGO, 2010). A imagem do castelo apresenta-se como um labirinto escuro, sombrio, repleto de portas, sendo que uma única ganha destaque, com a imagem de uma borboleta 
e uma sombra. Bem ao centro, vislumbra-se o leito, com lençóis alvos. O texto que subjaz à imagem, posicionado no canto inferior direito, é: "E à noite o noivo chegou" (LAGO, 2010). Na lateral inferior direita, vê-se a sombra sorrateira, adentrando ao castelo.

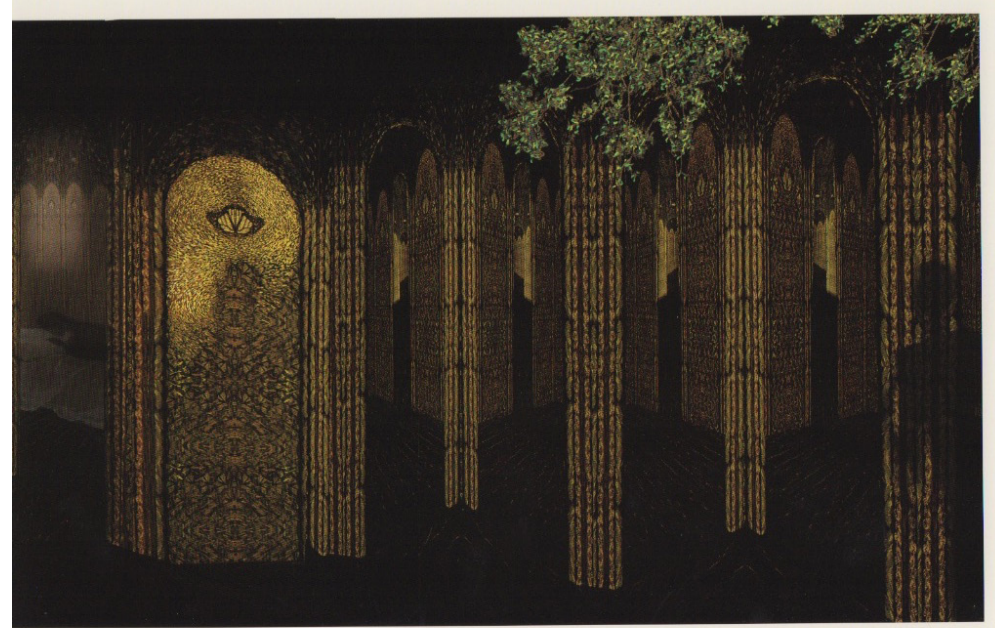

E à noite o noivo chegou.

Figura 2

O castelo como labirinto: "E à noite o noivo chegou".

As imagens labirínticas, noturnas, em tons dourados, com aspecto gótico recordam as imagens produzidas pelo cinema expressionista alemão, que se valia das sombras como expressão de uma realidade conturbada, onde o ser humano vivia uma crise de identidade, que se traduzia na deformação da diegese. Exemplo de imagens semelhantes podem ser encontradas nos filmes de Robert Wiene, como 
Gabinete do dr.Calegari (1920) e Fausto (1926), onde a atmosfera sombria e distorcida recebe também influência da pintura barroca de Rembrandt.

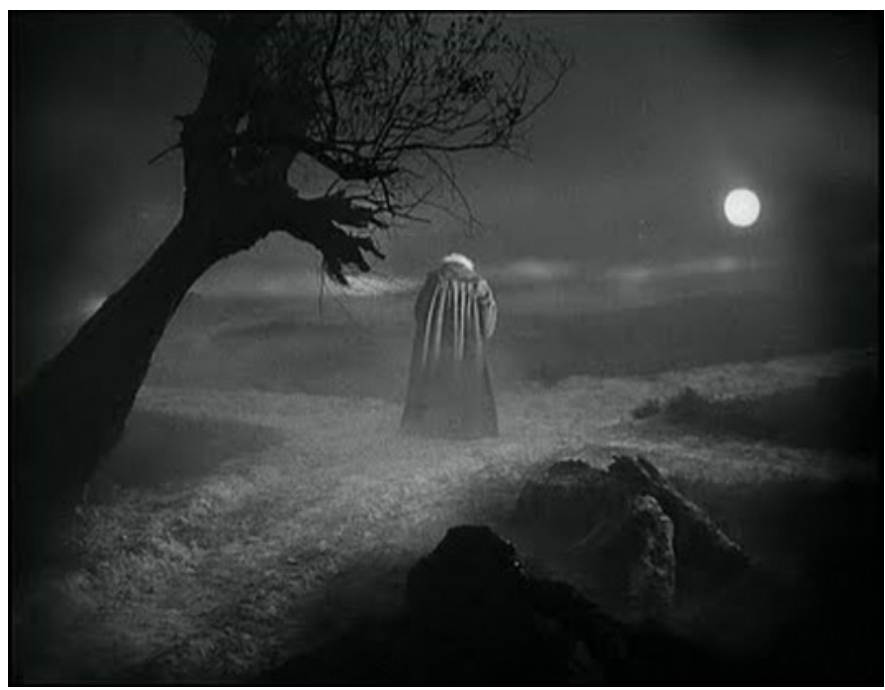

Figura 3

Fausto, 1926, direção Robert Wiene.

Por sua vez, o labirinto erguido por colunas compostas por uma infinidade de asas de borboletas remetem a M. C. Escher e suas obras, entre elas, Borboletas, de 1950, no estilo Op Art. Também é pertinente pensar na composição destas colunas a partir da arte fractal, ou seja, uma arte baseada na geometria fractal, caracterizada pela autoafinidade onde qualquer porção é idêntica ao todo e por detalhamento em todas as escalas, com estruturas labirínticas. 


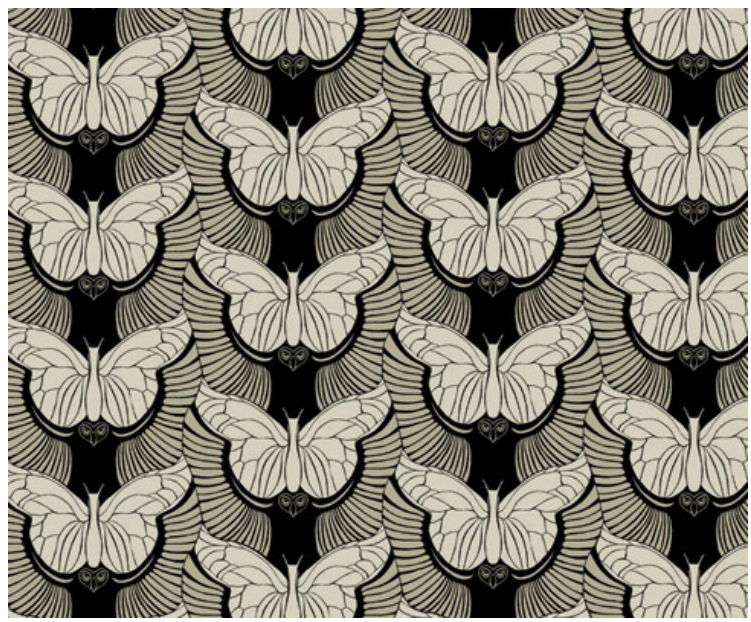

Figura 4

Borboletas, de Escher.

Adiante, observa-se o noivo já no interior do castelo, aparentemente rodeado por borboletas amarelas. A intertextualidade produzida pela imagem das borboletas amarelas trazem à memória o personagem Mauricio Babilônia, do romance de Gabriel García Márquez, Cem Anos de Solidão, cuja presença era sempre identificada pela personagem Renata Remedios (Meme), com quem Babilônia mantinha um relacionamento secreto, devido à presença das agitadas borboletas que o rodeavam, atribuindo-lhe um caráter mágico e encantador (GARCÍA MÁRQUEZ, 1967).

O texto de Psiquê informa que o noivo sempre chegava no escuro da noite e partia antes do amanhecer, pois ele avisara que ela não poderia vê-lo e, caso ela tentasse, o perderia. 
Psiquê estava feliz com o esposo, embora não pudesse olhálo; seu amor era forte, baseado na confiança e na atração que sentia por ele.

Um dia, as irmãs de Psiquê fizeram-Ihe uma visita. Sentiram inveja de sua felicidade, e por isso recordaram-lhe que o oráculo dissera que "o senhor do castelo era um monstro" (LAGO, 2010) e que, por isso, ela deveria vê-lo sem que ele soubesse. Convencida pelas irmãs, a princesa esperou seu amado adormecer e:

com uma lamparina e um punhal, descobrir como era a fera.

Ah! Deslumbramento! A fera que voa, queima e fere era o deus do amor.

Trêmula, Psiquê deixou cair uma gota de azeite da lamparina e sem querer queimou e feriu o próprio Eros. (LAGO, 2010)

A imagem que acompanha o texto mostra a sombra de Psiquê, ao centro, de braços abertos em direção ao amado, e a sombra de Eros na lateral direita do desenho, abandonando-a. Eros sente-se traído, visto que a amada prometera não tentar vê-lo.

Na sequência, a imagem aponta a personagem sozinha caminhando por uma paisagem ampla e um tanto escura, entre árvores e arbustos sem folhas, com sua sombra projetada sobre a relva. O texto revela: "Imediatamente, 
Afrodite, a deusa, a mãe furiosa, escondeu o filho machucado" (LAGO, 2010). Psiquê vaga pelo mundo em busca de Eros, em alguns momentos desejando a própria morte, até que um dia consegue suplicar a Afrodite pelo retorno de Eros.

Afrodite decide então vingar-se dela: impôs à jovem tarefas praticamente impossíveis: ela deveria separar milhares de grãos que estavam misturados uns aos outros. A ilustração mostra que ela contou com a ajuda das formigas para conseguir separar os grãos. A composição da imagem é bastante complexa, realizada a partir de arabescos organizados em linhas simétricas, losangos, formas ovais, sobre uma superfície clara, que destaca os insetos e a sombra de Psiquê.

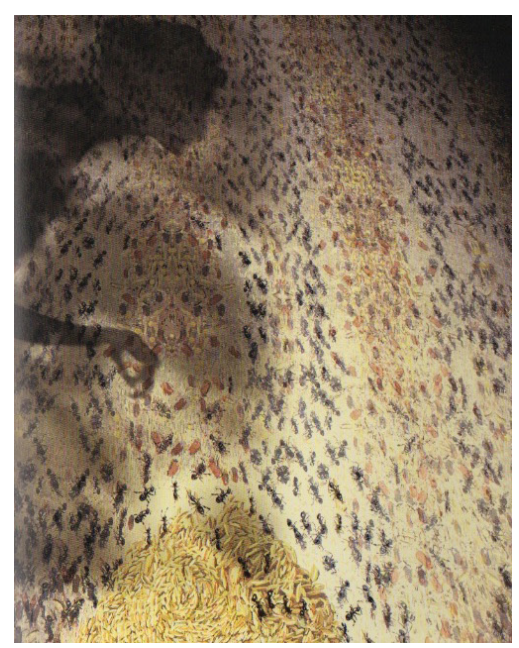

Figura 5

Formigas formando linhas e arabescos. 
Afrodite exige mais um trabalho a Psiquê: pediu-lhe um novelo dos fios de ouro das ovelhas ferozes. A imagem projeta a silhueta dela sobre um cenário que recorda o da obra Morte de Ofélia (1851-1852), de John Everett Millais. A sombra, projetada sobre a água, guarda uma minúscula borboleta na região do coração, como num jogo de espelhos. A referência à personagem Ofélia da tragédia shakespeariana Hamlet ganha sentido ao comparar-se a trajetória discrepante de Ofélia e Psiquê: Ofélia, cujo nome em grego significa "ajuda", "assistência", sucumbe ao amor e, ao invés de reivindicar/ conquistar Hamlet, enlouquece e morre, num implícito suicídio; Psiquê, embora pense em morrer, enfrenta as provas impostas por Afrodite para recuperar o ser amado. A sombra da jovem revela vida, pois há uma borboleta que bate as asas, em contraste com o corpo inerte de Ofélia. 


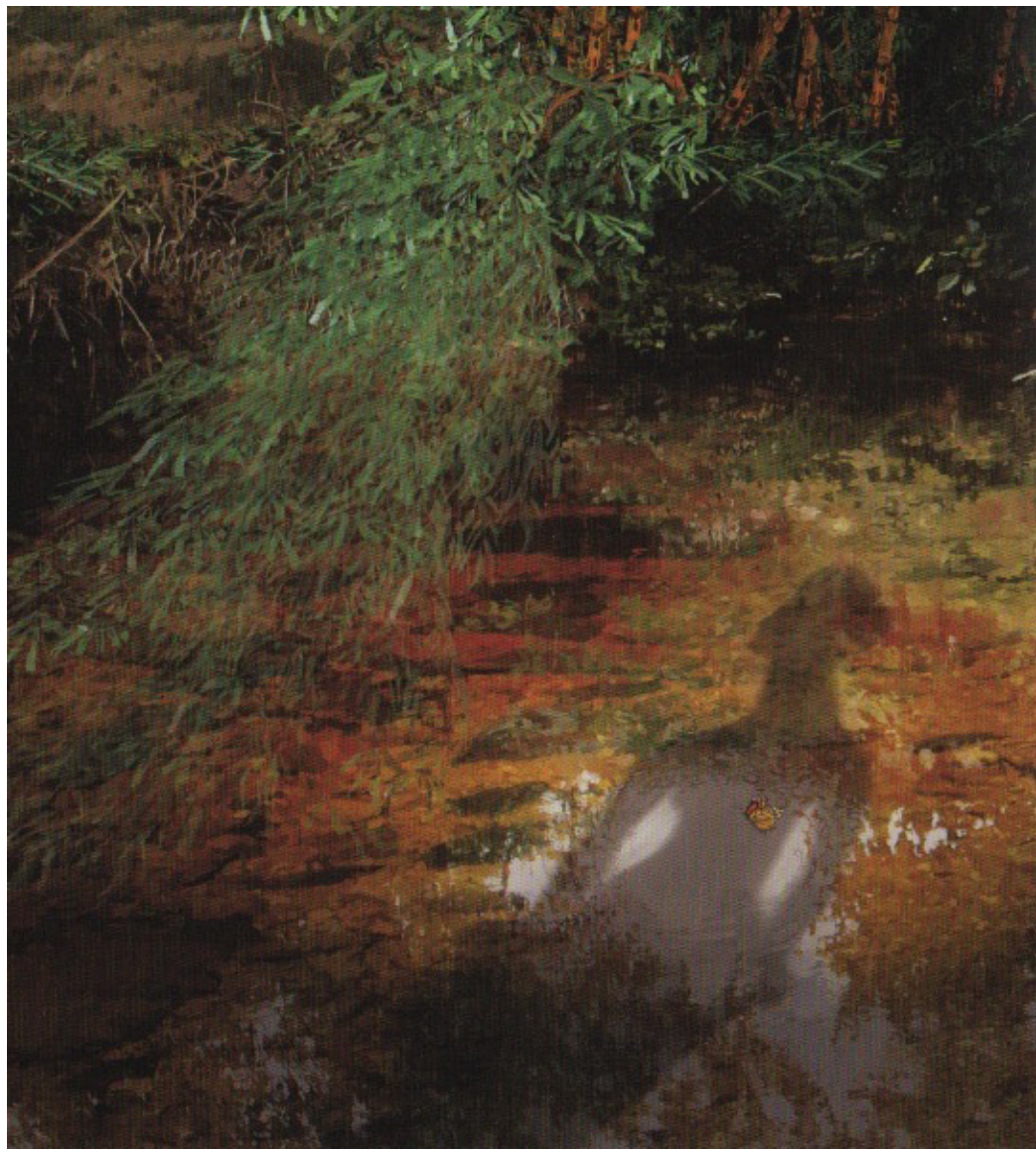

Figura 6

A sombra de Psiquê com uma borboleta projetada na água. 


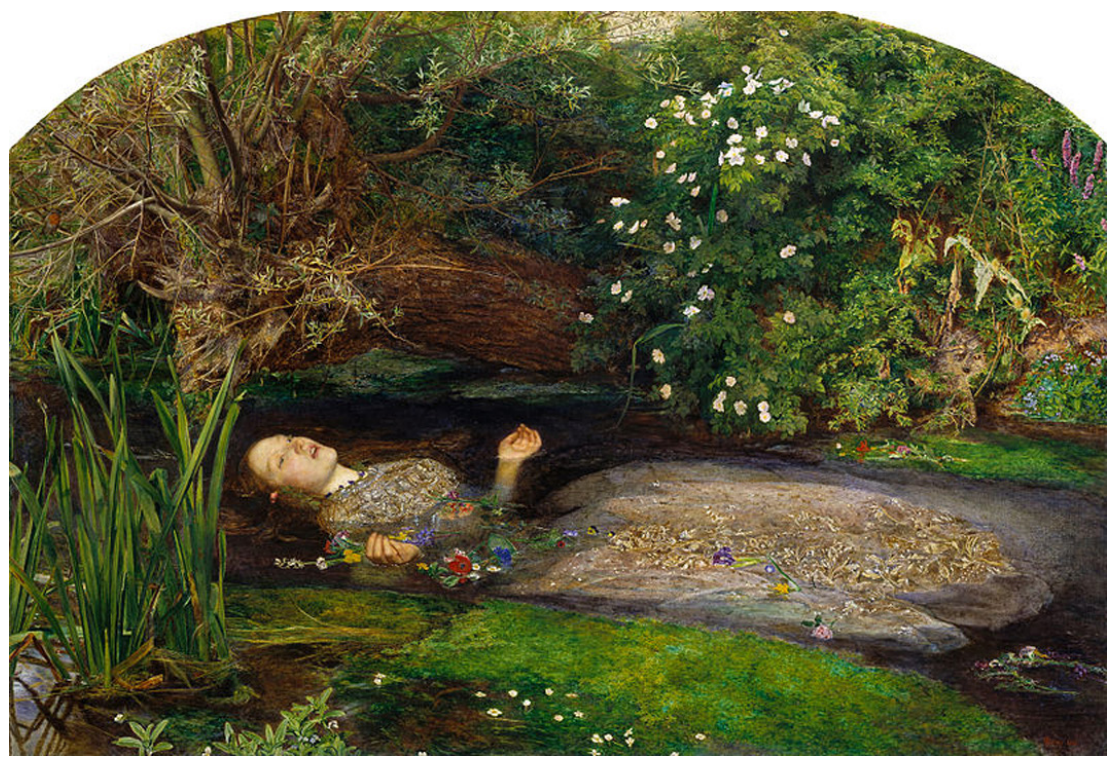

Figura 7

Morte de Ofélia, 1851, John Everett Millais.

No terço central da mesma imagem, encontram-se imagens camufladas, isto é, que se tornam visíveis apenas ao leitor atento, que descobre duas ovelhas que observam a cena e dois fusos com novelos dos fios de ouro, objeto da tarefa imposta a Psiquê por Afrodite. Uma das ovelhas (ou carneiro) ao fundo encara o leitor em meio aos galhos.

Após vencer o desafio de levar a lã de ouro das ovelhas ferozes, Afrodite quer "um vaso de água do mais profundo despenhadeiro" (LAGO, 2010), no qual habitam dragões, e sua formação é de pedras escorregadias. Através da intervenção mágica de uma águia que leva Psiquê por uma 
trilha segura, ela vence mais uma vez o desafio da deusa. $\mathrm{Na}$ mitologia grega, a águia é um atributo de Zeus, associada como "símbolo primitivo e coletivo do pai e de todas as figuras da paternidade" (CHEVALIER e GHEERBRANT, 2006, p.22). O desenho mostra uma queda d'água gigantesca, que remete ao Salto Angel, a maior queda d'água do mundo, localizada na Montanha Auyantepui, no Parque Nacional de Canaima, na Venezuela, país onde Angela Lago residiu.

Por fim, a personagem enfrentou a última e a pior das provações: a princesa deveria buscar um pouco da beleza guardada no inferno e trazê-la intacta numa caixa. O maior desafio seria vencer sua própria piedade, indo ao "inferno", topos equivalente ao Hades grego, o reino dos mortos, e "não estender a mão a ninguém, pois não a soltariam" (LAGO, 2010). Chegando às profundezas, avista Cáron, representado na ilustração como uma caveira numa canoa, referência ao barqueiro da mitologia, cuja função era transportar as almas dos mortos pelo rio Aqueronte. Segundo a crença helênica, os mortos pagavam pelos serviços de Cáron oferecendo-Ihe um óbolo e, para isso, depositava-se uma moeda na boca dos cadáveres, garantindo assim a viagem (KURI, 1994, p.70).

A ilustração destaca duas imagens sobre as águas do rio: inicialmente, lembram um amontoado de peixes 
mortos, grãos ou folhas mortas. No entanto, trata-se da inserção inusitada e com uma extrema força emocional: são imagens dos sapatos dos prisioneiros mortos no campo de concentração de Auschwitz-Birkenau, na Polônia, durante a Segunda Guerra Mundial. Esses sapatos fazem parte do Museu que hoje ocupa esse antigo campo de concentração. A imagem foi usada por Angela Lago para revelar a dificuldade da provação enfrentada por Psiquê: mesmo perante tanto sofrimento, ela deveria resistir e jamais estender a mão aos mortos. Pela imagem, os sapatos são metonímias dos mortos no Holocausto. Cabe ao leitor refletir como a princesa é capaz de encontrar forças para não se entregar às súplicas dos mortos no Holocausto. Ambas são imagens devastadoras que imprimem tristeza, medo e horror ao inframundo.

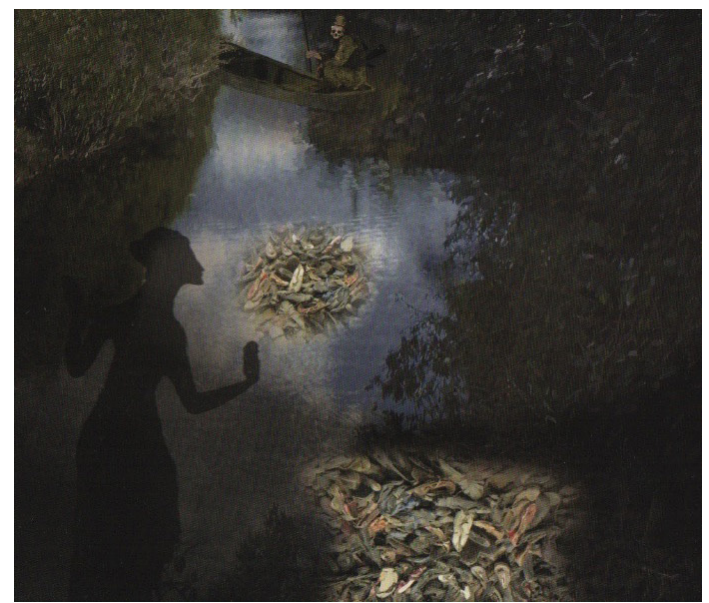

Figura 8

A sombra de Psiquê vai até o rio e se depara com Cáron e os sapatos (recorte). 


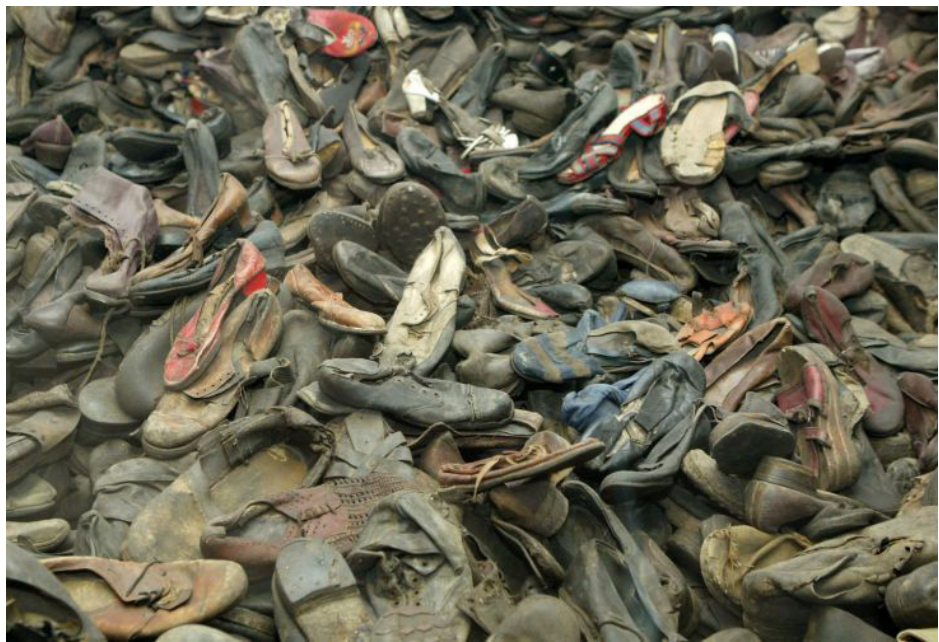

Figura 9

Foto de Fabrizio Bensch, Agência Reuters. Pilha de sapatos de prisioneiros expostos no museu de Auschwitz-Birkenau.

Depois de cruzar o rio da Morte, ela retorna bravamente com a caixa. Porém, a exemplo de Pandora, aquela superou todos os obstáculos menos a sua vaidade: ela abriu a caixa, liberando o sono profundo e mortal, que mantém a beleza e o esplendor ao fazer o tempo parar. Psiquê adormece profundamente, como se estivesse morta.

Novamente, é possível associar a imagem de Psiquê adormecida (figura 9) à imagem do quadro já citado, Morte de Ofélia, de Millais (figura 7), embora as cores ganhem mais brilho e luminosidade, visto que a princesa não está de fato morta, mas adormecida. 


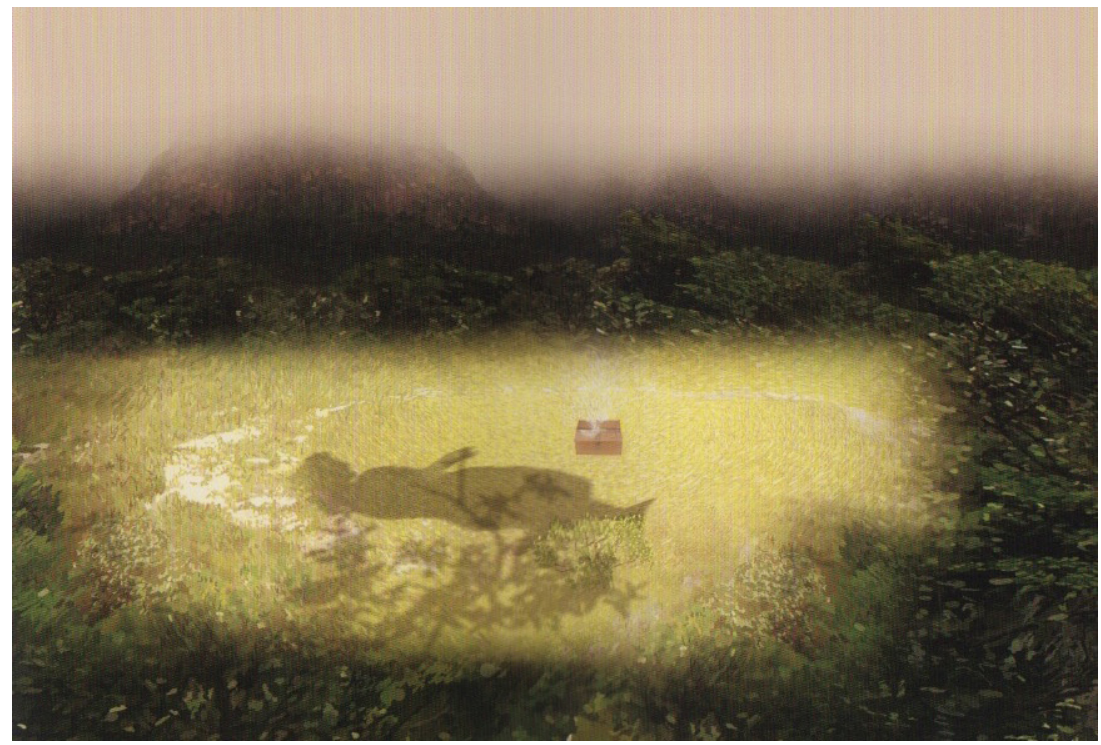

Figura 10

O corpo de Psiquê em sono profundo (recorte).

Na versão de Angela Lago, já curado da ferida provocada pela personagem, Eros deixa a casa da mãe e voa a toda velocidade à procura de sua amada e consegue chegar "a tempo de despertá-la antes que a morte a levasse" (LAGO, 2010). Na sequência, o texto da autora realiza uma elipse em relação à narrativa mitológica: Psiquê torna-se uma deusa, ambos têm uma filha chamada Prazer e vivem felizes no monte Olimpo.

Na mitologia, Zeus interfere em favor de Eros, que lhe pede ajuda para dar vida à jovem que está condenada ao sono eterno. Zeus se compadece do sofrimento de Eros e pede a 
Hermes que leve Psiquê à assembleia celestial. Lá, ela recebe uma taça de ambrosia, o néctar da imortalidade.

A ilustração de Angela Lago mostra os dois amantes no campo em frente ao castelo onde ambos habitavam. Eros oferece a mão a Psiquê, curvando-se diante dela. Nesta imagem, é ele que possui asas de borboleta, como se ambos fossem borboletas, almas unidas pela metamorfose do amor. A figura dela é dupla: uma sombra e uma silhueta que deixa à mostra uma tiara de princesa; ganha um caráter divino, superando a mortalidade, deixando a vida terrena de provações para trás, pois a força de sua vontade e sua alma revelaram o seu caráter, permitindo a sua metamorfose de mortal à ser divino.

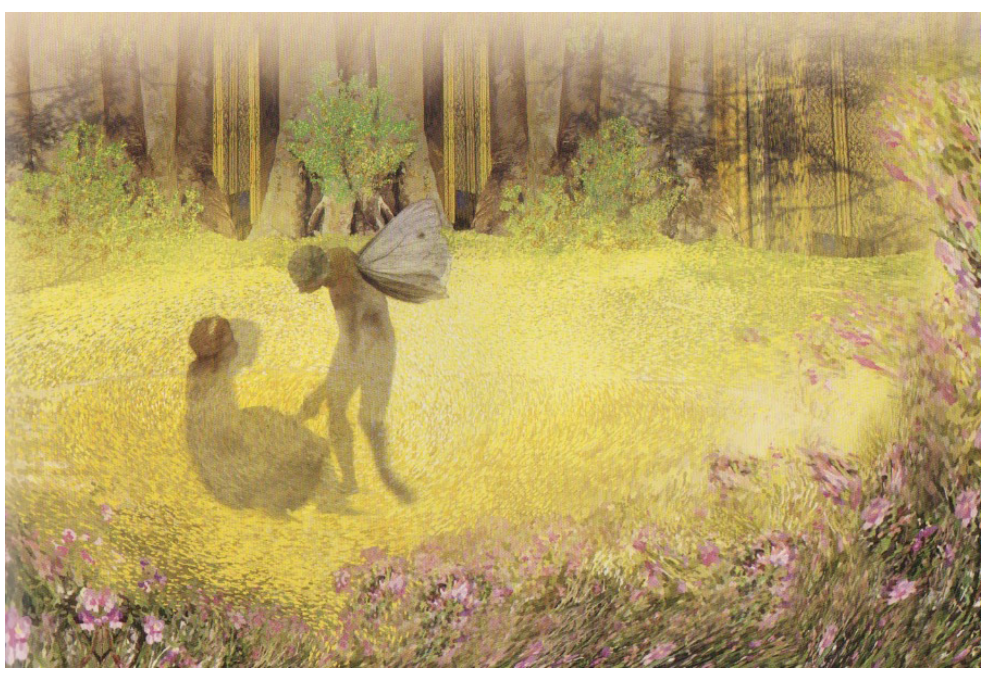

Figura 11

Psiquê com silhueta dupla e Eros com asas de borboleta. 
A modo de posfácio, além de uma biografia, o texto apresenta a história e revela algumas motivações da autora:

A versão do mito criada por Angela brinca de ocultar e revelar, assim como o livro narra a história de um monstro que nunca pode ser visto e de uma princesa que, de tão bela, não pode ser descrita. Só é possível enxergar o casal na sombra projetada no castelo e no rochedo, criada pela luz das estrelas. (LAGO, 2010, posfácio).

Como literatura infantil, o livro Psiquê tem a propriedade de encantar, brincar, aguçar os sentidos, despertar o interesse pelo texto e suas ilustrações, além de conter os ingredientes clássicos das histórias de fada ("era uma vez", a superação dos obstáculos para alcançar o amor e, claro, o "foram felizes para sempre").

Psiquê constitui uma "alegoria da imortalidade da alma [...] purificada pelos sofrimentos e infortúnios, e preparada, assim, para gozar a pura e verdadeira felicidade" (BULFINCH, 2006, p.96).

O contato que esta obra estabelece com o adulto, seja um mediador na leitura para crianças, professor-mediadorfacilitador, ou como adulto interessado num livro-ilustrado, vai puxando o fio de um novelo de ouro, uma descoberta a cada página com base em conhecimentos prévios, intertextualidade e outros contos, e narrativas que propõem 
versões do mito, como A Bela Adormecida e o sono eterno de Psiquê ou, ainda, A Bela e a Fera e a relação do grotesco e do sublime, com o amor e a pureza da alma superando as dificuldades. Para aqueles que têm conhecimento de artes, a intertextualidade com o não verbal estabelece através de obras de Escher, Millais, da arte fractal e do cinema expressionista. Partilharemos as palavras de Adélia Prado, que assina a quarta capa de Psiquê:

Não quero ferir a delicadíssima força deste livro feito de pura beleza. Rendome ao seu clima de sonho. [...] como é possível alguém perfurar um papel de fundo preto e me obrigar a dizer: é um céu estrelado! (ADÉLIA PRADO in LAGO, 2010).

\section{REFERÊNCIAS:}

Bensch, Fabrizio (2008). Foto - Pilha de sapatos de prisioneiros expostos em museu de Auschwitz-Birkenau. In http://viagem.uol.com.br/album/ polonia_marcha_album.htm\#fotoNav=18 Foto de, Agência Reuters. Acesso em dezembro/2014.

Buifinch, Thomas (2006). O livro de Ouro da Mitologia. Histórias de deuses e heróis (34a ed.). Rio de Janeiro: Ediouro.

Casirer, Ernst. (2000). Linguagem e mito. São Paulo: Perspectiva.

Chevalier, Jean \& Gheerbrant, Alain (2006). Dicionário de Símbolos (20a ed.). Rio de Janeiro: José Olympio.

Coelho, Nelly Novaes (1984). Literatura Infantil: História, teoria, análise (3a ed.). São Paulo: Quíron.

Eliade, Mircea (2004). Mito e realidade (6a ed.). São Paulo: Perspectiva. 
García Márquez, Gabriel (1967). Cem anos de solidão. Rio de Janeiro: Record.

Hunt, Peter (2010). Crítica, teoria e literatura infantil. São Paulo: Cosac Naify.

Kury, Mário da Gama (1994). Dicionário de mitologia grega e romana (3a ed.). Rio de Janeiro: Jorge Zahar.

Lago, Angela (2010). Psiquê. São Paulo: Cosac Naify.

Leoni, G. D. A. (1967). Literatura de Roma (7a ed.). São Paulo: Nobel.

Pullman, Philip (1989) Invisiblepictures, in Signal (n. 60, p. 171) Apud HUNT, P. (2010). Crítica, teoria e literatura infantil. São Paulo: Cosac Naify. PLATÃO (s/d). Diálogos. Mênon, Banquete, Fedro. Rio de Janeiro: Ediouro. PUGLIESI, Márcio (2003). Mitologia Greco-Romana. Arquétipos dos deuses e heróis. São Paulo: Madras. In http://www.angela-lago.net.br/ bio2.html. Acesso em Dezembro/2014.

http://www.angela-lago.net.br/palestra.html Acesso em dezembro /2014. http://classes.yale.edu/fractals/Panorama/Art/FracAsArt/FracAsArt. html Acesso em dezembro /2014.

http://enciclopedia.itaucultural.org.br/pessoa6168/angela-lago>Acesso em dezembro /2014.

http://imaginariop.blogspot.com.br/2012/05/cinema-arte-maislembrada-do.html Imagem de Fausto, 1926. Acesso em dezembro /2014. http://www.wikiart.org/en/m-c-escher/butterflies. Acessoem dezembro/2014.

Sandra Trabucco Valenzuela tem Doutorado em Literatura HispanoAmericana pela Universidade de São Paulo (USP), é Pós-Doutoranda em Literatura Comparada (USP), Especialista em História da Arte, professora de Arte e Cultura da Universidade Anhembi Morumbi, SP. É tradutora e escritora, integra o grupo de Estudos Diálogos híbridos na formação do leitor (FFLCH/USP). 